Technical Article

\title{
Revitalization of an amateur sports field with emerald grass
}

\author{
Patrick Luan Ferreira dos Santos ${ }^{1 *}\left(\mathbb{0}\right.$, Matheus Vinícios Leal do Nascimento ${ }^{1}$, \\ João Victor $\operatorname{Costa}^{1} \mathbb{C}^{\circ}$, Roberto Lyra Villas Bôas ${ }^{1}$ (]) \\ ${ }^{1}$ Universidade Estadual Paulista (UNESP), Faculdade de Ciências Agronômicas, \\ Departamento de Ciência Florestal, Solos e Ambiente, Botucatu-SP, Brazil.
}

\begin{abstract}
With the increasing popularization of football (soccer), new technologies have arrived in Brazil that assist in the maintenance of sports fields, making it possible to increase the quality of turfgrass in both professional and amateur fields. Thus, the revitalization process has become fundamental in sports fields installed with emerald grass to improve game performance and turfgrass development. The objective of this study was to revitalize an amateur sports field in the interior of São Paulo state, Brazil, planted with emerald grass. The conditions of the field were initially assessed and a set of revitalization procedures were carried out from November 2019 to March 2020 to improve turfgrass quality, including: chemical analysis of the soil and liming; mowing of the grass and disposal of clippings; soil decompaction through aeration with solid tines; application of sand (top dressing); pest and weed control; planting of new sod; fertilization and maintenance. Technical training with employees was also conducted for subsequent field maintenance. All tested operations were essential and necessary to improve the aesthetics and quality of the amateur sports field, so that the turfgrass could be revitalized and ready for use in soccer matches.
\end{abstract}

Keywords: Zoysia japonica, topdressing, sports field, turfgrass.

\section{Resumo}

\section{Revitalização de um campo de futebol amador de grama esmeralda}

Com a popularização do futebol, novas tecnologias para auxiliar na manutenção de campos esportivos chegaram no Brasil, o que possibilitou aumentar a qualidade de áreas gramadas, seja em campos de alta ou de baixa performance. Onde, o processo de revitalização se tornou fundamental em campos esportivos instalados com grama esmeralda, para melhorar o desempenho do jogo e desenvolvimento do gramado. Assim, o objeto do presente trabalho foi realizar a revitalização de um campo esportivo de baixa performance no interior de São Paulo instalado com grama esmeralda. Foram realizadas operações de novembro a março, onde inicialmente verificou-se as condições do campo, e foram realizados um conjunto de procedimentos para melhorar a qualidade do gramado, sendo eles: análise química do solo e calagem, corte das folhas e descarte das aparas, descompactação do solo com perfuração com pinos maciços, aplicação de areia (Topdressing), controle de pragas e plantas daninhas, plantio de novos tapetes de grama, adubação de plantio e de manutenção e capacitação técnica para funcionários, para posterior manutenção do campo. Observou-se que todos esses conjuntos de operações foram essenciais e necessários para melhorar a estética e a qualidade do campo esportivo de baixa performance, podendo assim, o gramado ser revitalizado e pronto para uso em partidas de futebol.

Palavras-chave: Zoysia japonica, topdressing, campo esportivo, gramado.

\section{Introduction}

Emerald grass (Zoysia japonica), which features stoloniferous and rhizomatous growth and an emerald green color, is the main turfgrass sold in Brazil (Mota et al., 2019; Santos et al., 2020). It is resistant to trampling due to the intertwining of its rhizomes and stolons, presents a dense cover, and shows mid-level demand for nitrogen fertilization (Godoy et al., 2012; Santos and Castilho, 2018a). For many years, emerald grass was the main species used in professional soccer fields in Brazil (Godoy et al., 2012); however, it is also currently used in landscaping (Oliveira et al., 2018; Santos et al., 2020), and for golf fairways (Nicoludis and Daniels, 2019), training centers for sports teams, and amateur soccer fields (Pardim, 2020).

\footnotetext{
*Corresponding author: patricklfsantos@gmail.com

https://doi.org/10.1590/2447-536X.v26i4.2212

Received June 15, 2020 | Accepted July 27, 2020| Available online Sept 30, 2020

Licensed by CC BY 4.0 (https://creativecommons.org/licenses/by/4.0/)

Area Editor: Petterson Baptista da Luz
} 
With regard to sports fields, there has been a recent radical change in the concept of turfgrass quality (Conmebol, 2019). With the popularization of soccer, new technologies for planting and maintaining turfgrass have proliferated, which has led to a significant increases in the quality of Brazilian sports fields. It is essential for sports turfgrass to present particular characteristics that enable an excellent game and do not injure the players, and the grass must be maintained in superior condition (Kuhn, 2015; Mateus et al., 2020)

The quality of the turfgrass surface in sports fields, such as soccer fields, is critical for the match to be correctly carried out (Chang et al., 2017; Straw et al., 2018). The appearance of weeds, lack of an appropriate fertilization program, and uneven and compacted soil, are some of the problems encountered in many Brazilian sports fields with turfgrass (Associação Nacional Grama Legal, 2020). During a soccer match there can be no interruptions due to the accumulation of water on the surface which may be caused by unexpected rains, causing puddles to form (Santos and Castilho, 2018b).

Compacted soil can interfere with the quality of the field, as a poorly drained field will disrupt not only the sports event, but will also directly affect the development of the turfgrass and its maintenance (Mateus et al., 2017). Furthermore, compaction combined with incorrect fertilization compromises the growth of roots due to a lack of oxygen in the soil, leading to poor absorption of nutrients, greater incidence of disease, and difficulty in trimming the field. All of these factors affect athletes' practice of the game (Chang et al., 2017; Straw et al., 2018, Santos and Castilho, 2018b; Associação Nacional Grama Legal, 2020).

Thus, techniques must be conducted periodically in sports fields to improve turfgrass conditions (Conmebol, 2019), such as soil decompaction with large aeration systems (Malleshaiah et al., 2018; Kother, 2018). This improves soil aeration and enables better root development, water penetration, and nutrient absorption (Ryan lawn and Tree, 2016). Meanwhile, the application of sand (top dressing) improves the uniformity of the field and increases drainage, and appropriate weed control and fertilization programs are essential to ensure the health of the turfgrass (Conmebol, 2019). However, it is necessary that these techniques are performed by trained personnel to maximize the quality of the sports field.

Thus, the object of this study was to implement a range of techniques to revitalize an amateur sports field in the interior of São Paulo state, Brazil, planted with emerald grass.

\section{Methodology}

\section{Study location}

The project was carried out in the interior of the state of São Paulo, where the region's climate is Cwa according to the Köppen climate classification, with dry winters and hot and rainy summers. The annual average temperature is 20.3 ${ }^{\circ} \mathrm{C}$, with an average maximum and minimum temperature of 26.1 and $15.3{ }^{\circ} \mathrm{C}$, respectively. The average annual rainfall is $1,428.4 \mathrm{~mm}$, with the rainy season concentrated in the months of December, January, and February, and the average annual relative humidity is $75 \%$, but can reach levels below 15\% (Cunha and Martins, 2009). The project began in November 2019 and continued until March 2020. Initially, visits to the field were made to identify techniques to begin the revitalization of the turfgrass.

The soccer field is planted with emerald grass and has in a total area of 9,296 $\mathrm{m}^{2}(83 \times 112 \mathrm{~m})($ game area + perimeter with players' rest area). The field is located within a recreational park in the city and is surrounded by a fence; however, its gates remain open for anyone who wishes to enter. Thus, the field experiences heavy pedestrian traffic (Figure 1e), many children play in the field, and animals are allowed to graze on the grass (Figures $1 \mathrm{c}$ and $\mathrm{d}$ ).

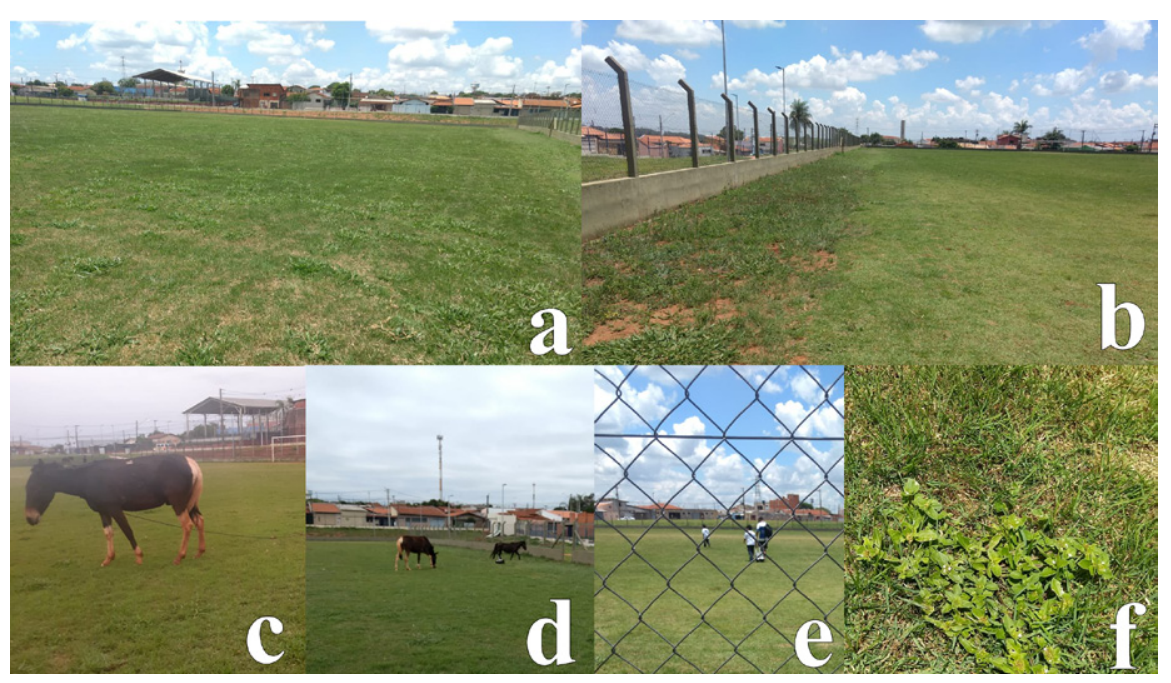

Figure 1. Field conditions before starting the revitalization. a) view of the field contaminated with weeds; b) perimeter area without turfgrass and contaminated with weeds; $\mathrm{c}$ - d) grazing horses; e) pedestrian traffic across the field; f) detail of weeds in the field. 
One of the major problems observed was that the turfgrass was highly contaminated (Figure 1a, before) with narrow-leaf weeds, such as brachiaria (Brachiaria spp.), lemongrass (Cymbopogon citratus), and tiririca (Cyperus rotundus), as well as broad-leaf weeds, such as caruru (Amaranthus viridis) and purslane (Portulaca oleracea) (Lorenzi, 2014). Furthermore, there were areas contaminated with bahiagrass (Paspalum notatum), another type of turfgrass that is more rustic, with longer leaves and hairy ends, but is less resistant to trampling than emerald grass (Souza et al., 2020). These plants are highly invasive, as they show rapid growth (Lorenzi, 2014) and generate shade, which hinders not only the growth of the emerald grass, but also affects lawn density (closed and flawless turfgrass), alters its visual (aesthetic) appearance, and prevents correct soccer play, all of which are undesirable for sports fields (Gazola et al., 2016; Santos et al., 2019).

Pests were also identified, including termite mounds and anthills at various points in the field. According to Henriques (2003), these pests attack grasses and hinder their development.

The soil and subsoil conditions where the emerald grass was planted were unknown in terms of fertility. Similarly, no information was available regarding whether there had been correct application of lime and fertilization before laying the sod, which is essential for sports fields (Mateus et al., 2017; Santos and Castilho, 2018b).

The area does not have an irrigation system installed to supply water during periods without rain (autumn/winter). This makes maintenance of the grass difficult during dry periods (Aldahir, 2012), and prevents the continuous use of the field for games, training and other routine activities.
The turfgrass was uneven (Figure 1b) with many holes. According to Mateus et al. (2017), this impedes the use of the field for a soccer match. As such, holes must be filled by leveling the field which enables the use of the field without risk of injury to the players (Conmebol, 2019).

The perimeter of the soccer field, or the area in which game play does not occur and serves the purpose of a rest area for players and movement of authorized personnel, had a total of $1,100 \mathrm{~m}^{2}$. However, this perimeter was without turfgrass and had a significant amount of weeds (Figure 1a), mainly brachiaria, which end up serving as a seed bank for lawn contamination.

Thus, after documenting all of these issues, a set of measures were taken to begin the revitalization of the sports field, including identifying the necessary equipment, materials and labor, as well as a cost analysis to start the project. As a first step, the field was closed so that only authorized personnel had access to it and signs were installed to inform the public.

Field operations were conducted during the summer and followed a set of procedures to improve the quality of the turfgrass as recommended by Melo (2016) for revitalizing sports fields.

\section{Soil analysis and liming}

To collect soil samples from the site, on November 25, 2019 , the field was divided into 6 quadrants, and $10 \mathrm{sub}-$ samples were taken from each quadrant that make up the base of the turfgrass, to compose a total sample for each quadrant. Soil was collected with the aid of a dial auger to a depth of $20 \mathrm{~cm}$. These samples were then sent to a laboratory and chemical analyses to assess fertility were performed using an adapted methodology based on Raij et al. (2001).

Table 1. Chemical analysis of soil in the different quadrants.

\begin{tabular}{|c|c|c|c|c|c|c|c|c|c|c|}
\hline \multirow{2}{*}{ Quadrant } & \multirow{2}{*}{$\begin{array}{c}\mathbf{p H} \\
\left(\mathrm{CaCl}_{2}\right)\end{array}$} & \multirow{2}{*}{$\begin{array}{c}\text { O.M. } \\
\left(\mathrm{g} \mathrm{dm}^{-3}\right)\end{array}$} & \multirow{2}{*}{$\begin{array}{c}\mathbf{P}_{\text {resina }} \\
\left(\mathrm{mg} \mathrm{dm}^{-3}\right)\end{array}$} & $\mathbf{H}+\mathbf{A l}$ & $\mathbf{K}$ & $\mathrm{Ca}$ & Mg & BS & CEC & \multirow{2}{*}{$\begin{array}{l}\text { V } \\
\%\end{array}$} \\
\hline & & & & \multicolumn{6}{|c|}{ - } & \\
\hline Q1 & 5.1 & 36 & 15 & 42 & 2.4 & 30 & 11 & 44 & 85 & 51 \\
\hline Q2 & 6.3 & 39 & 11 & 20 & 2.0 & 89 & 10 & 101 & 121 & 83 \\
\hline Q3 & 5.9 & 35 & 15 & 24 & 2.5 & 78 & 15 & 95 & 119 & 80 \\
\hline Q4 & 5.4 & 34 & 13 & 33 & 2.5 & 34 & 10 & 46 & 79 & 58 \\
\hline Q5 & 6.4 & 20 & 7 & 11 & 0.9 & 59 & 9 & 69 & 80 & 86 \\
\hline Q6 & 6.9 & 29 & 6 & 11 & 1.2 & 120 & 9 & 131 & 141 & 93 \\
\hline
\end{tabular}

After analyzing soil fertility (Table 1), only two quadrants were identified as requiring limestone application (Q1 and Q4), since base saturation was below that recommended $(65 \%)$ for sports fields (Mateus et al., 2017). The limestone applied was dolomitic, with a PRNT of $72 \%$ (Table 2 ). 
Table 2. Laboratory analysis of limestone.

\begin{tabular}{|c|c|c|c|c|c|c|c|c|}
\hline \multicolumn{3}{|c|}{ \% Passing } & \multicolumn{5}{c|}{ Result in \% } \\
\hline sieve10 & sieve20 & sieve50 & $\mathrm{CaO}$ & $\mathrm{MgO}$ & $\mathrm{RE}$ & $\mathrm{NP}$ & $\mathrm{RTNP}$ & moisture \\
\hline 99.8 & 98.4 & 60.3 & 39.4 & 11.8 & 83.4 & 86 & 72 & 0.1 \\
\hline
\end{tabular}

The liming was performed manually in each of the quadrants (Q1 and Q4). The limestone was spread evenly over the turfgrass area and then watered, to raise the $\mathrm{V} \%$ to 65 .

\section{Results and Discussion}

\section{Lawn mowing}

After the closure of the field to prevent access by unauthorized personnel, the turfgrass surface was mowed intermittently. The first cut was to a height of $1.5 \mathrm{~cm}$, which is slightly below that recommended for emerald grass by Sampaio (2012) of 2 to $4 \mathrm{~cm}$. However, we followed Melo's recommendations (2016) who suggests that in a process of revitalizing sports fields, a first short cut of the grass is required to standardize the area and locate possible imperfections. These defects can include holes and scalping, which are areas where turfgrass has grown excessively and shaded the lower part of the turf, after cutting they look white/yellowish (Aldahir, 2012; Aldahir, 2015; Conmebol, 2019). All mowing was conducted using a Husqvarna ${ }^{\circledR}$ LT 1597 tractor (Figure 2a) with its own collector (Figure 2b) and two rotary mower blades that can cut an area of up to $1.5 \mathrm{~m}$ in width with each pass. The tractor was maintained in gear 3 , at an accelerated speed.

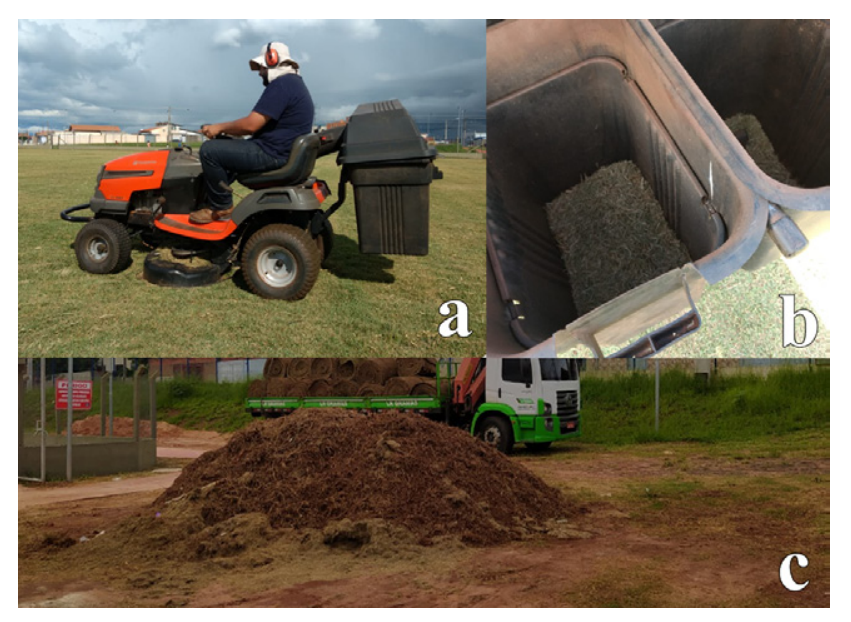

Figure 2. a) Rotary blade mowing tractor; b) clippings collector coupled to the tractor; c) volume of clippings discarded after cutting.

Mowing was conducted every 7 to 10 days, as needed, since the revitalization techniques were carried out at the time of greatest growth of the turfgrass (spring/summer), due to the heat and intense rains (Godoy et al., 2012 ). However, Sampaio (2012) recommends not cutting more than $1 / 3$ of the grass height, and as such, the height was generally kept at $2 \mathrm{~cm}$.

The clippings were discarded outside the field, and pilled within the recreational park (Figure 2c), until it was later removed by city hall. However, people would sometimes collect the material for use as organic fertilizer for use on small farms. As Santos and Castilho (2016) note, turfgrass clippings are an excellent material for use in composting and organic fertilization.

\section{Pest and weed control}

The use of chemicals to control pests and weeds was necessary, since infestations were significant and negatively affecting the quality of the turfgrass. Specific post-emergent herbicides were used to control broadand narrow-leaf weeds (Tapia, 2003). An initial spray solution of $200 \mathrm{~L} \mathrm{ha}^{-1}$ was applied over the total area (Table 3). The solution was applied with the aid of a 4-nozzle sprayer that covers a width of $1.5 \mathrm{~m}$, coupled to a Husqvarna ${ }^{\circledR}$ LT 1597 tractor (Figures 3a, c and d). Application of herbicides using a backpack sprayer (10L) were also carried out throughout the revitalization process at specific points on the field where the weeds again began to emerge. 
Table 3. Herbicide spray.

\begin{tabular}{|c|c|}
\hline \multicolumn{2}{|c|}{ For 100L spray } \\
\hline Broadleaf control herbicide (Volcane - MSMA) & $1000 \mathrm{ml}$ \\
\hline Herbicide control of ciperaceas (Sempra) & $100 \mathrm{~g}$ \\
\hline Broadleaf control herbicide (Norton - 2.4-D) & $500 \mathrm{ml}$ \\
\hline Narrowleaf control herbicide (Facet- Quincloraque) & $350 \mathrm{~g}$ \\
\hline Adhesive spreader (Iharaguen) & $100 \mathrm{ml}$ \\
\hline
\end{tabular}

For pest control, termite mounds were initially knocked down manually with a pickaxe, and a rinse syrup at a dose

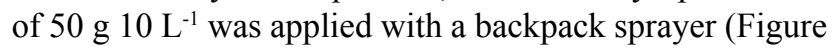

2b). For the control of anthills, a spray was applied twice across the total area, at 10-day intervals, using the sprayer and tractor described above.

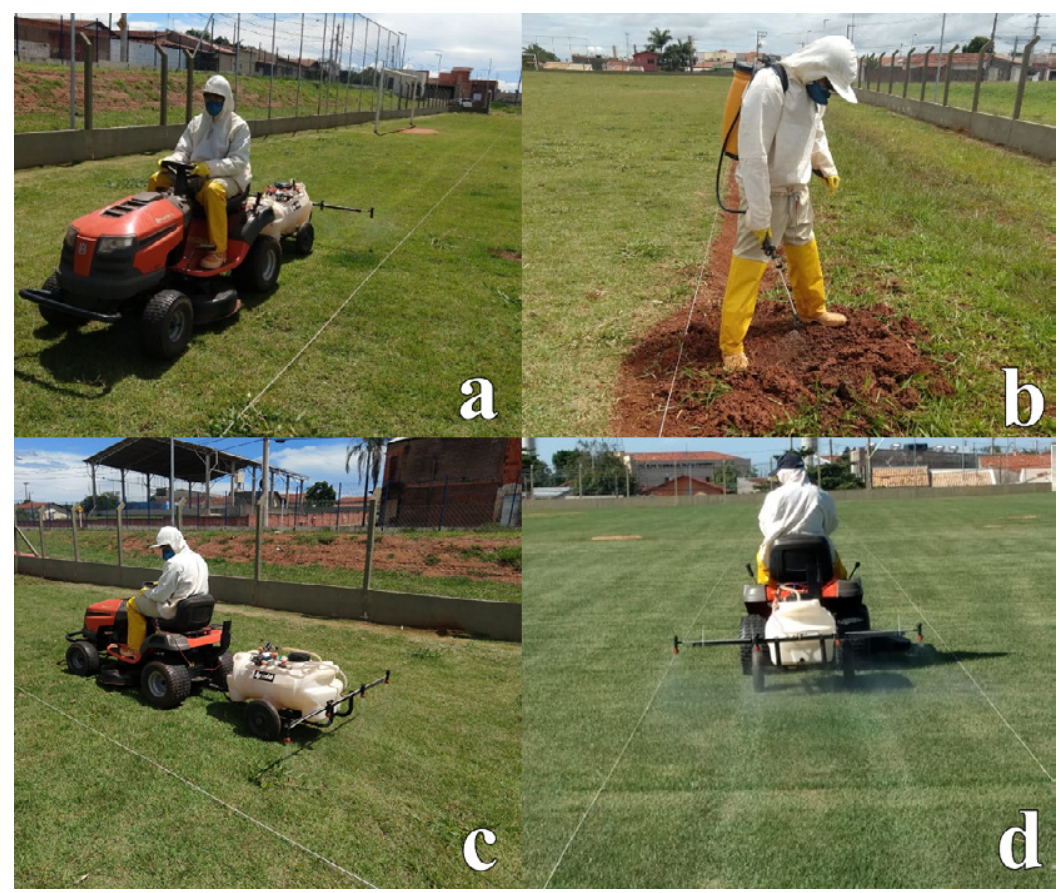

Figure 3. Spraying of the field to control weeds with a sprayer attached to the tractor (a, c, d) and pests backpack sprayer (b)

In the perimeter where no turfgrass was growing but there was a significant invasion of weeds, glyphosate (Roundup) was applied to completely desiccate the plants in the area, at a dose of $500 \mathrm{~g}$ for $100 \mathrm{~L}$ of water. After 20 days, the dried plant material was removed with a plate stripper (Classen Hydro-Drive Sod Cutter, SCHV-18/5.5-Honda engine), leaving the soil exposed. The perimeter was then leveled for later planting with sod rolls of emerald grass.

It is important to note that for all applications, PPE (Personal Protective Equipment) was used for to ensure personnel safety.

\section{Aerating and topdressing}

One of the main problems found in sports turfgrass is compaction resulting from excessive trampling. Compaction is mainly due to inappropriate material used as a base, generally clay soils that are easily compacted (Campanelli, 2003). Thus, as the field was uneven and without maintenance for a long period of time, two subsequent procedures were performed: aeration of the soil and application of sand.

Initially, the soil was aerated across the total area with to a depth of $10 \mathrm{~cm}$. For this, a Carrier $\left(\right.$ Redemix $\left.{ }^{\circledR}\right)$ manual tractor (specific for use in turfgrass) was used, with a 3-point system, lifting capacity of up to $475 \mathrm{~kg}$ and wide tires for better traction and balance, thus minimizing soil compaction. A Verti-Drain ${ }^{\circledR} 1513$ aerator was attached to the tractor (Figure $4 a$ and $b$ ), which is specific for sports fields, with 24 tines of $15 \mathrm{~cm}$ in length and $1 \mathrm{~cm}$ in diameter, and a working width of $1.3 \mathrm{~m}$. During the procedure, the tractor remained in third gear, at a reduced speed, providing approximately 408 holes per $\mathrm{m}^{2}$ (Figures $4 \mathrm{c}$ and $\mathrm{d}$ ). Thus, these perforations across the field broke up the soil layer without damaging the surface, preventing soil compaction and facilitating root growth as well as the penetration of air, water, light, nutrients, which enable good shoot development (Campanelli, 2003; Malleshaiah et al., 2018; Kother, 2018; Conmebol, 2019). 


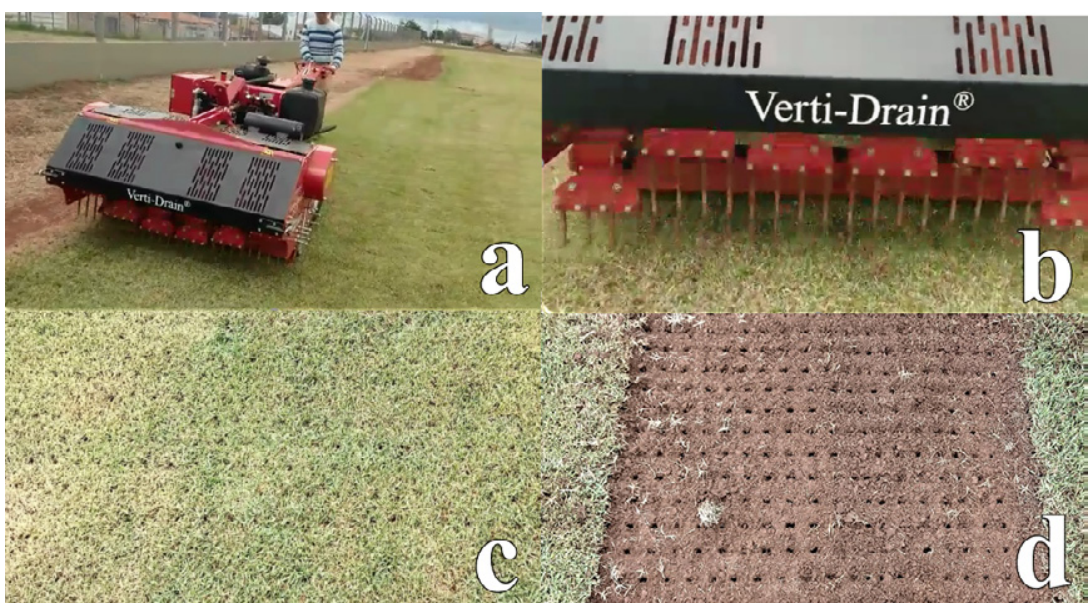

Figure 4. a) equipment for aerating the soil; b) detail of the Verti-Drain ${ }^{\circledR}$ attachment that perforates the soil; c) perforations after aeration of turfgrass; d) perforations after aerating in exposed soil.

This procedure also helps to remove fine particles from the soil surface layer, modify the profile in fields built on clay soils, and control the thatch, which is an organic layer that forms below the carpet and prevents water penetration (Campanelli, 2003; Conmebol, 2019). As such, it creates holes across the field that can be filled by sandy materials, such as the medium sand that was applied in the subsequent procedure.

The application of sand was conducted using the same Carrier tractor described above, coupled with a Top Dresser Rink 1010, which is commonly used for sports lawns. This sand applicator is powered by the hydraulic force of the tractor, and is $1.8 \mathrm{~m}$ in length, with a working width of applied sand of $1.5 \mathrm{~m}$ and sand storage capacity of $1 \mathrm{~m}^{3}$ (Figure 6a). The sand used was purchased from a local establishment. However, before purchase, a sample was taken to a physics laboratory for granulometric analysis (table 4) to verify if the sand was within the standards established for sports fields (Aldahir, 2015). The granulometric analysis showed that it was similar to the minimum value and suitable for application in the field (Figure 5).

Classification curve of the sandy layer

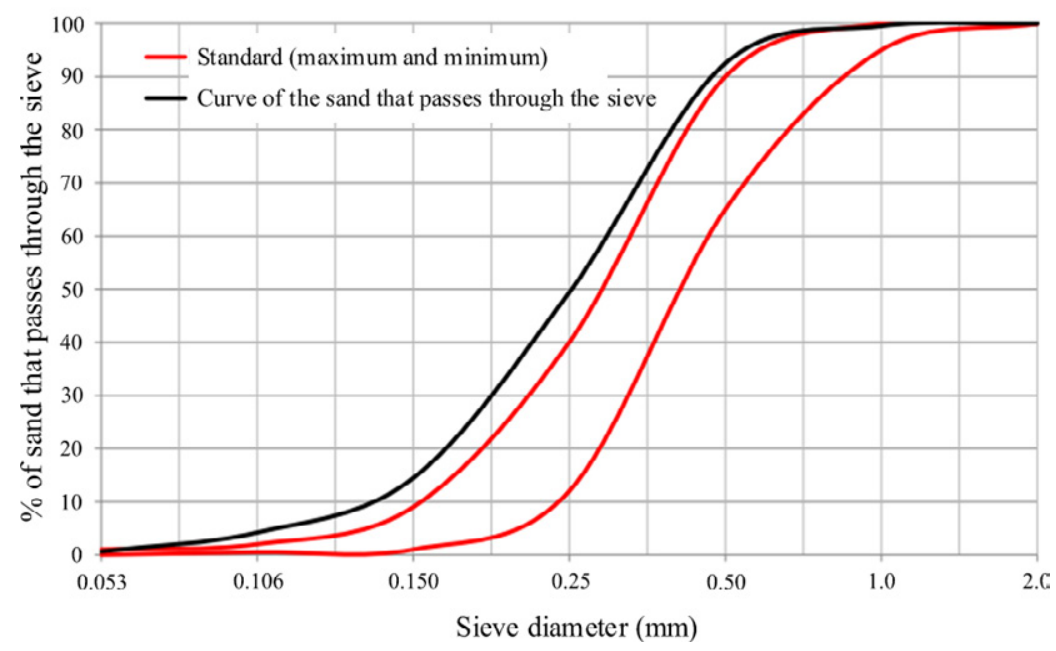

Figure 5. Sand classification curve for application in the field. 
Table 4. Physical analysis of sand applied to the field

\begin{tabular}{|c|c|c|c|c|c|c|c|}
\hline \multirow{2}{*}{ Sample } & \multicolumn{7}{|c|}{ Sieve diameter $(\mathrm{mm})$} \\
\hline & 2.00 & 1.00 & 0.50 & 0.25 & 0.15 & 0.106 & 0.053 \\
\hline \multirow[b]{2}{*}{ Sand } & \multicolumn{7}{|c|}{$\%$ of sand that passes through the sieve } \\
\hline & \multirow[t]{2}{*}{100} & 99.5 & 92.5 & \multirow[t]{2}{*}{49.4} & 14.5 & 4.2 & 0.6 \\
\hline \multicolumn{3}{|r|}{ Sand } & & & \multirow{2}{*}{ Clay } & \multirow{2}{*}{\multicolumn{2}{|c|}{ Silte }} \\
\hline \multicolumn{2}{|c|}{ Coarse } & Thin & \multicolumn{2}{|c|}{ Total } & & & \\
\hline \multicolumn{8}{|c|}{$\left(\mathrm{g} \mathrm{Kg}^{-1}\right)$} \\
\hline \multicolumn{2}{|c|}{499} & 484 & \multicolumn{2}{|c|}{983} & 14 & \multicolumn{2}{|c|}{3} \\
\hline
\end{tabular}

Approximately $100 \mathrm{~m}^{3}$ of sand was applied to the total area (Figure 6b), which corresponded to a thickness of $1 \mathrm{~cm}$ on the lawn (Figure 6c). A Bobcat filled the Top Dresser Rink 1010 with sand as needed. After the sand application, the field was brushed with a metallic structure to spread the sand evenly over the field and allow it to enter the holes and adjust the micro-leveling without damaging the lawn.

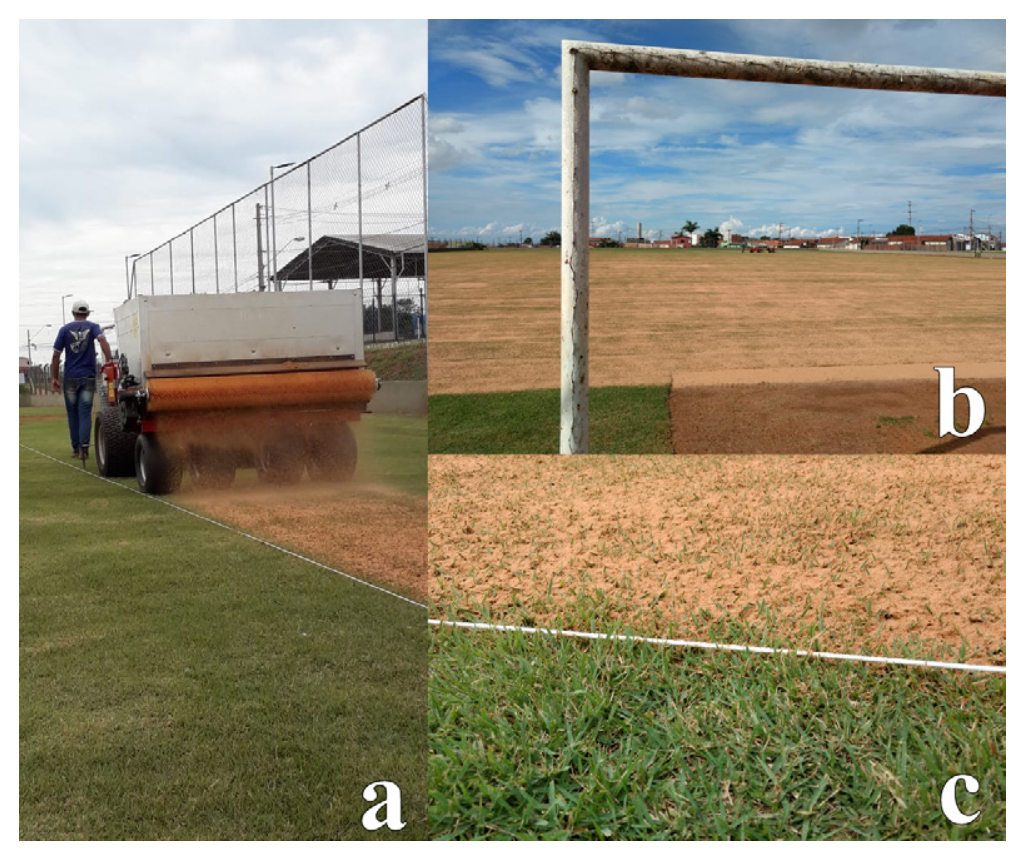

Figure 6. Application of sand in the field. a) instrument used to apply sand; b) detail of the field area where sand was applied; c) detail of turfgrass with and without sand.

\section{Planting new sod}

As previously described, the perimeter of the field was not planted with turfgrass, and as such the plant biomass was removed, and the exposed soil was leveled smoothly with a hoe. The same procedure was carried out at specific points across the field that showed flaws or wear of the turfgrass due to intense trampling, such as the goal area (Figure 7c). This area is the most affected during a game due to constant movement of goalkeepers (Conmebol, 2019). In these places, the worn-out turf was removed and the ground leveled with sand. 


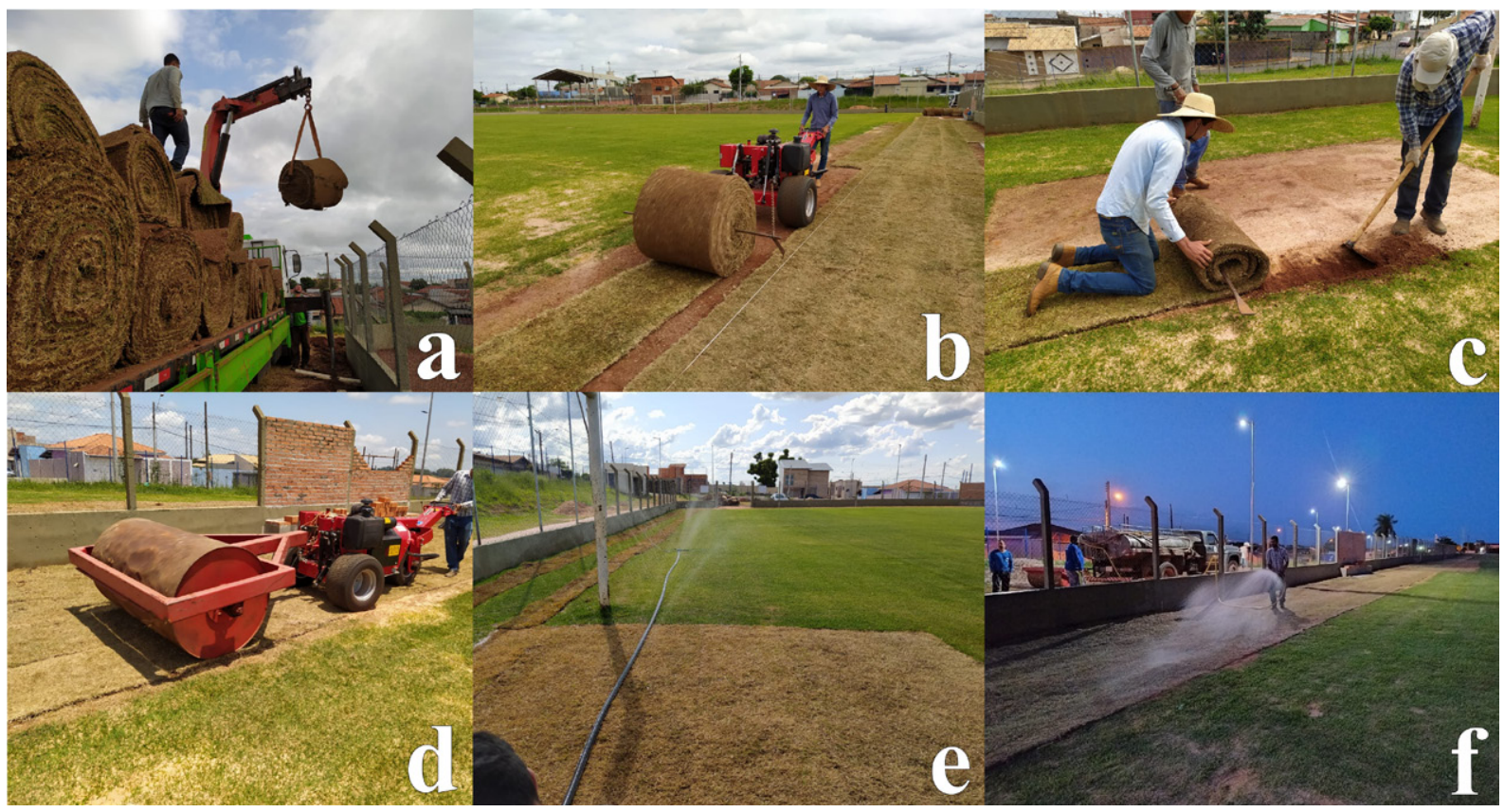

Figure 7. a) Munck crane unloading rolls of sod; b) planting the turfgrass on the field perimeter; c) planting the sod in the goal area; d) compacting with a roller; e) irrigation with garden sprinklers attached to a hose; f) manual irrigation with water from an irrigation truck.

In each of these areas, fertilization was conducted before planting to improve the development of turfgrass and to stimulate the root system. A commercial fertilizer 4-14-8 was used, following the recommendation of Santos and Castilho (2018a) of $60 \mathrm{~g} \mathrm{~m}^{-2}$ for emerald grass.

The total area that required the placement of sod was $1,500 \mathrm{~m}^{2}$, and the turf was planted using of Big Rolls of $0.75 \times 40 \mathrm{~m}$. The turf was produced in the municipality of Itapetininga, SP and supplied by the company LR Gramas. The rolls were unloaded with the help of a Munck crane (Figure 7a), and the sod rolls were laid with a metallic structure coupled to the Carrier tractor (Figure 7b). Subsequently, in the recently planted areas, a 132 $\mathrm{kg}$ compactor roller (Figure 7d) was driven twice over the area to better fix the turf and to eliminate possible air bubbles between the sod and the soil (Mateus et al., 2017).

According to Santos and Castilho (2018b), after planting the sod, extensive irrigation is necessary to better fix the turf and ensure there are no major stresses to the plant. However, as the field does not have an irrigation system, the grass was watered daily with garden sprinklers attached to a hose (Figure 7e) and also with the help of an irrigation truck that carried water to the side of the field (Figure $7 \mathrm{f}$ ) on days when there was no rain.

\section{Maintenance fertilization}

In sports fields, maintenance fertilization is a routine practice that maintains the quality of the turfgrass, such as intense green, damage recovery, resistance to trampling, and attack by pests and diseases (Godoy et al., 2012). Higher quantities of Nitrogen are required for turfgrass, especially in sports fields (Santos et al., 2019). Thus, during the revitalization period, fertilization was conducted three times in January, February and March 2020, based on the requirements of the field. The source used was bran ammonium sulfate $(21 \% \mathrm{~N}$ and $24 \% \mathrm{~S})$, using the recommended dose of $400 \mathrm{~kg} \mathrm{~N} \mathrm{ha}^{-1}$ year $^{-1}$, considering the seasonal requirements of the plant: $25 \%$ in Spring; $35 \%$ in summer; $25 \%$ in autumn; and $15 \%$ in winter (Godoy et al., 2012). Thus, for fertilization, $35 \%$ of $400 \mathrm{~kg} \mathrm{ha}^{-1}$ year $^{-1}$ was used as a basis, meaning that $140 \mathrm{~kg} \mathrm{ha}^{-1}$, divided into three 30-day applications, were applied between January and March 2020. For this, a fertilizer was coupled to the Husqvarna $^{\circledR}$ tractor, and the area fertilized was always well marked (Figure 8). 


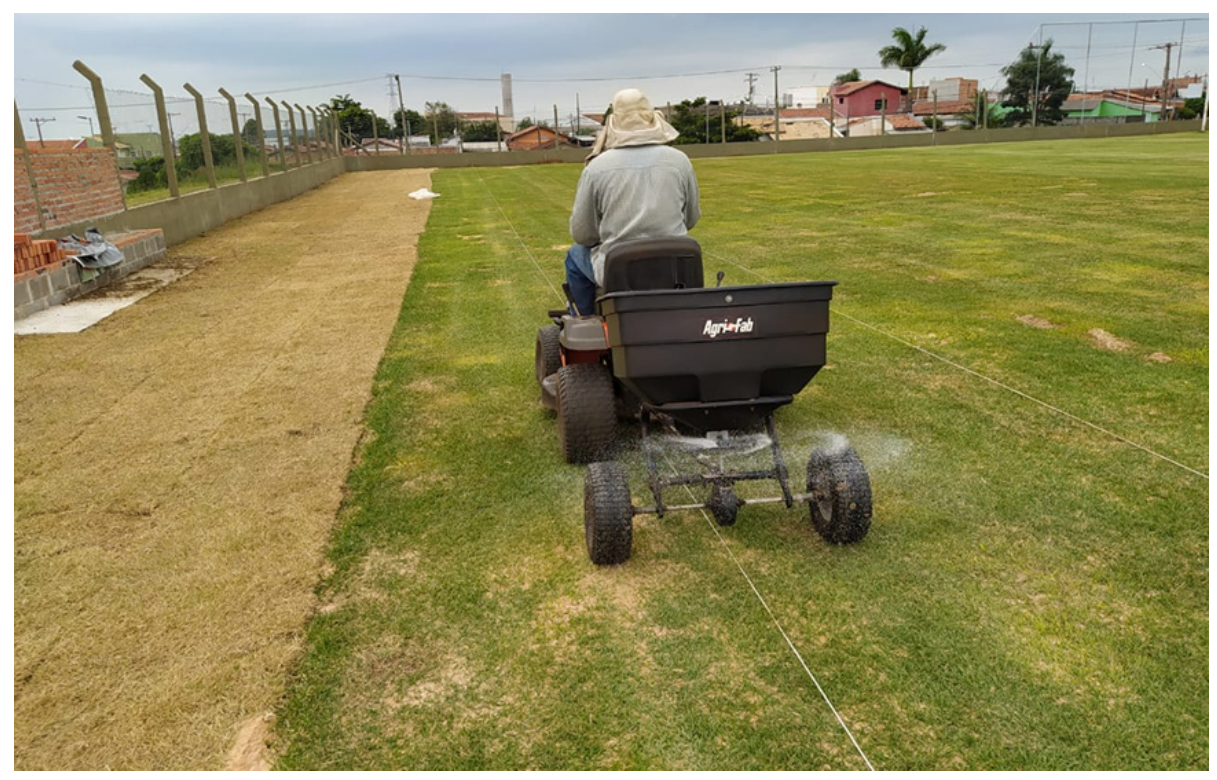

Figure 8. Maintenance fertilizer with ammonium sulfate in the field.

\section{Technical training}

Before the end of the revitalization process, technical training was carried out with city officials to demonstrate the procedures that were adopted and instruct them on how to care for the maintenance of the field. Technical training consisted of lectures discussing the main practices carried out in managing sports fields, the use of pesticides, and the importance of the quality of a turfgrass surface. Furthermore, it was possible to demonstrate the machines and instruments that can be used to maintain sports turfgrass, as well as other common grasses used in Brazil, highlighting their main characteristics and possible uses.

\section{Field delivery and completion}

After all procedures were complete, the amateur sports field, which was previously of poor quality (Figure 9a), was revitalized and the turfgrass was ready for use in early March (Figure 9b), with a useful pitch area of $105 \times 68 \mathrm{~m}(7,140)$.

\section{Conclusions}

Thus, adopting practices and measures used in professional fields for this amateur field, it was possible to provide the qualities necessary to ensure an excellent soccer match. However, the consistent application of maintenance procedures must be adopted, including correct nutritional management and pest, disease, and invasive plant control. Meanwhile, the intensity of games must be balanced to avoid extensive wear on the turfgrass.

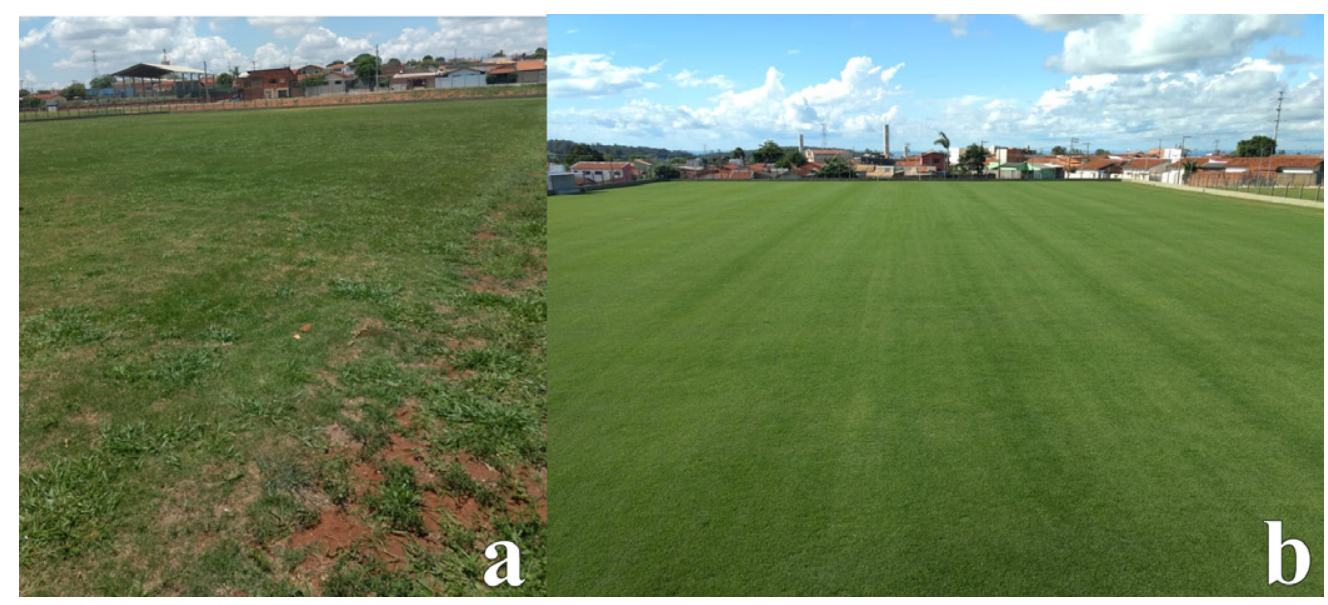

Figure 9. a) field before revitalization; b) field after revitalization 


\section{Author contribution}

PLFS: Operations coordinator, description of materials used, technical consultant, data collection and analysis, critical review. MVLN: Operations coordinator, description of materials used, technical consultant, data collection and analysis, critical review JVC: Machine operator, field analysis and data collection, critical review RLVB: Project coordinator, critical review, approval of final version, work advisor.

\section{Acknowledgements}

The authors would like to thank the agronomist João Paulo Jacob Limpo de Abreu for his assistance and collaboration in carrying out the project. We also thank the town of Botucatu-SP, and particularly Mayor Mário Eduardo Pardini Affonseca for his confidence in conducting the revitalization of the sports turfgrass.

\section{References}

ALDAHIR, P.C.F. Campos esportivos: Aeração - parte II. Infograma, 2015. Available at: <http://infograma.com. br/aeracao-parte-ii/> Accessed on: March $23^{\text {th }} 2020$.

ALDAHIR, P.C.F. Composição e uso de campos esportivos. In: BACKES, C.; GODOY, L.J.G.; MATEUS, C.M.D.; SANTOS, A.J.M.; VILLAS BÔAS, R.L.; OLIVEIRA, M.R. Tópicos atuais em gramados III. Botucatu: FEPAF, 2012. p.175-184.

ASSOCIAÇÃO NACIONAL GRAMA LEGAL. Tudo o que você precisa saber sobre gramados esportivos. 2020. Available at: $<$ https://gramalegal.com/consumidorgramados-esportivos>. Accessed on: March $23^{\text {th }} 2020$.

CAMPANELLI, M.V.J. Principais máquinas e implementos usados na manutenção de gramados. In: VILLAS BÔAS, R.L.V.; GODOY, L.J.G. SIGRA: Produção, Implantação e Manutenção. Botucatu: GEMFER, 2003. p. 56-71.

CHANG, K.H.; POWERS, J.E.; LYONS, E. Water restriction impact on surface hardness and soil volumetric water content on recreational sports fields. International Turfgrass Society Research Journal, v.13, n.1, 614, 2017. DOI: https://doi.org/doi:10.2134/itsrj2016.09.0832

CONMEBOL - CONFEDERAÇÃO SUL-AMERICANA DE FUTEBOL. Guia básico de preparação de campos de futebol. Assunção, Paraguai: Editora CONMEBOL, 2019. 60p.

CUNHA; A.R.; MARTINS, D. Classificação climática para os municípios de Botucatu e São Manuel, SP. Irriga, v.14, n.1, p.1-11, 2009. DOI: http://dx.doi.org/10.15809/ irriga.2009v14n1
GAZOLA, R.P.D.; BUZETTI, S.; GAZOLA, R.N.; CASTILHO, R.M.M.; TEIXEIRA FILHO, M.C.M.; CELESTRINO, T.S.; DUPA, E. Nitrogen dose and type of herbicide used for growth regulation on the green coloration intensity of Emerald grass. Ciência Rural, v.46, n.6, p.984-990, 2016. DOI: http://dx.doi.org/10.1590/0103$8478 \mathrm{cr} 20150276$

GODOY, L.J.G.; VILLAS BÔAS, R.L.; BACKES, C.; SANTOS, A.J.M. Nutrição, Adubação e Calagem para produção de gramas. Botucatu: FEPAF, 2012. 146p.

HENRIQUES, E.S. Principais pragas, doenças e plantas daninhas dos gramados cultivados. In: VILLAS BÔAS, R.L.V.; GODOY, L.J.G. SIGRA: Produção, Implantação e Manutenção. Botucatu: GEMFER, 2003. p.43-55.

KOTHER, M. Effects of working with the Verti-Drain or planet air on the water infiltration rate at the golf tee. European Journal of Turfgrass Science, v.49, n2, p.27$32,2018$.

KUHN, M. Projeto gramados esportivos copa do mundo FIFA 2014. In: MATEUS, C.M.D.; VILLAS BÔAS, R.L.; ANDRADE, T.F.; OLIVEIRA, M.R.; BACKES, C.; SANTOS, A.J.M.; GODOY, L.J.G. Tópicos atuais em gramados IV. Botucatu: FEPAF, 2015. p.23-34

LORENZI, H. Manual de identificação de plantas daninhas: plantio direto e convencional. 7ed. Nova Odessa: Plantarum, 2014. 384p.

MALLESHAIAH, S.K.; MURUGAIAH, J.; GOVINDASWAMY, V.; GANGA, M.; SURAKSHITHA, N.C. Influence of aerification technique on recuperative potential of warm season turfgrasses. Indian Journal of Agricultural Sciences. v.88, n.5, p.779-785, 2018.

MATEUS, C.M.D.; CASTILHO, R.M.M.; SANTOS, P.L.F.; MOTA, F.D.; GODOY, L.J.G.; VILLAS BÔAS, R.L. Nutrients exportation by Tifdwarf bermudagrass from golf course greens. Ornamental Horticulture, v.26, n.3, p.422-431, 2020. DOI: https://doi.org/10.1590/2447-536X.v26i3.2229

MATEUS, C.M.D.; TAVARES, A.R.T.; OLIVEIRA, M.R.; JACON, C.P.R.P.; SARTORI, M.M.P.; FERNANDES, D.M.; VILLAS-BÔAS, R.L. Influence of substrate base on sports field covered with bermuda grass. Ornamental Horticulture, v.23, n.3, p.319-328, 2017. DOI: https://doi. org/10.14295/oh.v23i3.1104.

MELO, A. Revitalização de gramados esportivos. Mundo Husqvarna: Profissionais do campo - Gramados. 2016. Available at: <http:/www.mundohusqvarna.com.br/ coluna/revitalizacao-de-gramados-esportivos/ $>$. Accessed on: November $23^{\text {th }} 2020$. 
MOTA, F.D.; VILLAS BÔAS, R.L.; MATEUS, C.M.D.; SILVA, T.B.G. Sewage sludge compost in zoysia grass sod production. Revista Ambiente \& Água, v.14, n.1, e2301, 2019. DOI: https://doi.org/10.4136/ambi-agua.2301

NICOLUDIS, Z.; DANIELS, J. The ins and outs of zoysiagrass fairway management. USGA: Green Section Record, v.54, n.11, 2019.

OLIVEIRA, N.B.; OLIVEIRA, J.F.V.; SANTOS, P.L.F.; GAZOLA, R.P.D.; CASTILHO, R.M.M. Avaliação do estado nutricional de três gramados ornamentais em Ilha Solteira-SP: um estudo de caso. Revista LABVERDE, v.9, n.1, p.96-119, 2018. DOI: http://dx.doi.org/10.11606/ issn.2179-2275.v9i1p96-119

PARDIM, J. Qual é a grama ideal para plantio em Campo de Futebol. Portal das gramas, 2020. Available at: $<\mathrm{http} / / /$ www.portaldasgramas.com.br/gramas-para-campo-defutebol\#: : :text=Tanto $\% 20 \mathrm{a} \% 20$ grama $\% 20$ Esmeralda $\% 20$ quanto, $\% 2 \mathrm{C} \% 20$ fazendas $\% 2 \mathrm{C} \% 20$ entre $\% 20$ outros).>. Accessed on: November $23^{\text {th }} 2020$.

RAIJ, B. van; CANTARELLA, H.; QUAGGIO, J.A.; FURLANI, A.M.C. Recomendações de adubação e calagem para o Estado de São Paulo. Campinas: Instituto Agronômico, 1996. 285p.

RYAN LAWN \& TREE. The benefits of aeration. 2016. Available at: <https://ryanlawn.com/the-benefits-ofaeration/>. Accessed on: May 10th 2020.

SAMPAIO, A.H. Manutenção de gramados ornamentais. In: BACKES, C.; GODOY, L.J.G.; MATEUS, C.M.D.; SANTOS, A.J.M.; VILLAS BÔAS, R.L.; OLIVEIRA, M.R. Tópicos atuais em gramados III. Botucatu: FEPAF, 2012. p.192-200.

SANTOS, P.L.F.; CASTILHO, R.M.M. Caracterização físico-química de diferentes substratos e sua influência no desenvolvimento da grama esmeralda. Tecnologia \& Ciência Agropecuária, v.10, n.6, p.21-26, 2016.
SANTOS, P.L.F.; CASTILHO, R.M.M. Resposta da grama esmeralda em função de diferentes fertilizantes e substratos. Cultura Agronômica, v.27, n.3, p.354-365, 2018a. DOI: https://doi.org/10.32929/2446-8355.2018v27n3p354-365

SANTOS, P.L.F.; CASTILHO, R.M.M. Substrates in the development of a sports turfgrass "Tifton 419". Ornamental Horticulture, v.24, n.4, p.138-144, 2018 b. DOI: https://doi.org/10.14295/oh.v24i2.1155

SANTOS, P.L.F.; CASTILHO, R.M.M.; GAZOLA, R.P.D. Pigmentos fotossintéticos e sua correlação com nitrogênio e magnésio foliar em grama bermuda cultivada em substratos. Acta Iguazu, v.8, n.1, p. 92-101, 2019.

SANTOS, P.L.F.; SILVA, P.S.T.; MATOS, A.M.S.; ALVES, M.L.; NASCIMENTO, M.V.L.; CASTILHO, R.M.M. Aesthetic and sensory quality of Emerald grass (Zoysia japonica) as a function of substrate cultivation and mineral fertilization. Ornamental Horticulture, v.26, n.3, p.381-389, 2020. DOI: https://doi.org/10.1590/2447-536X. v26i3.2216

SOUZA, F.H.D.; CAVALLARI, M.M.; GUSMÃO, M.R. Produção comercial de sementes de Paspalum notatum var. notatum. São Carlos: Embrapa Pecuária Sudeste, 2020a. 22p.

STRAW, C.M.; SAMSON, C.O.; HENRY, G.M.; BROWN, C.N. Does variability within natural turfgrass sports fields influence ground-derived injuries? European Journal of Sport Science, v.18, n.6, p.898-902, 2018. DOI: https:// doi.org/10.1080/17461391.2018.1457083

TAPIA, D. Herbicidas em gramados. In: VILAS BÔAS, R. L.; GODOY, L. J. G. SIGRA: Manejo de gramas na produção e em gramados formados. Botucatu: GEMFER, 2004. p.236-251. 